\title{
Annual bacterial production in relation to benthic microalgal production and sediment oxygen uptake in an intertidal sandflat and an intertidal mudflat
}

\author{
Leon M. Cammen* \\ Bigelow Laboratory for Ocean Sciences, West Boothbay Harbor, Maine 04575, USA
}

\begin{abstract}
In order to investigate the controls of bacterial abundance and production in marine sediments, bacterial production determined by uptake of ${ }^{3} \mathrm{H}$-thymidine, microalgal production and sediment oxygen uptake was investigated monthly for 1 yr in 2 benthic systems, an intertidal mudflat and an intertidal sandflat. There was a closer coupling between these rates in the sandflat than in the mudflat that may have been due to the more dynamic nature of the sandflat. The parameters measured in this study fell into 2 groups based on the similarity between their annual totals or mean abundances for the mudflat and for the sandflat. Although microalgal biomass, gross production, and sediment oxygen uptake were similar for both areas, bacterial biomass, bacterial production, and sediment organic carbon were all 4 to 5 times higher in the mudflat than in the sandflat. Estimated annual turnovers of the bacterial population were 52 for the sandflat and 59 for the mudflat. Temperature was the factor that had the greatest influence on bacterial production, explaining 55 to $57 \%$ of seasonal variation in specific growth rate. Bacteria appeared to respond to the increase in temperature in late winter-early spring more quickly than the rest of the sediment community; this would imply that the input of organic matter to the benthos from an early spring bloom, occurring in colder waters, might result in a less efficient transfer of energy to the macrofauna than would occur with a later bloom.
\end{abstract}

\section{INTRODUCTION}

Bacteria are important to the cycling of organic matter through marine sediments, both in terms of remineralization of nutrients and organic matter, and in terms of production of particulate carbon (Fenchel \& Blackburn 1979, van Es \& Meyer-Reil 1982, Meyer-Reil 1984). In the latter regard, the presumed role of the bacteria has evolved from being a major supplier of energy to deposit feeders and other detritivores to one of being important mainly in terms of nitrogen and various micronutrients (Phillips 1984, Cammen 1989, Lopez et al. 1989). Knowledge of the controls of bacterial abundance and production is necessary if we are to understand the transfer of organic production, either

\footnotetext{
- Present address: National Sea Grant College Program, R/OR1, 1335 East-West Highway, Silver Spring, Maryland 20910, USA
}

sedimented or in situ, through the sediments to higher trophic levels.

With the recent introduction of the thymidine technique (Moriarty \& Pollard 1981, Fuhrman \& Azam 1982, Moriarty 1986) for measuring bacterial production, it is now possible to investigate directly the relationship of the bacteria to other environmental factors instead of relying on inferences drawn from biomass data or uptake of other radiolabeled metabolites. However, there have been few studies that have taken advantage of this technique to investigate the role of bacteria in marine sediments and those have been limited in scope (see Cole et al. 1988, van Duyl \& Kop 1990 for reviews). In a series of projects from 1984 to 1987, I investigated bacterial production and grazing by meiofauna on bacteria in both intertidal and subtidal sediments. The results presented here show the relationship among the annual cycles of bacterial production, microalgal production and sediment oxygen uptake in 2 benthic systems, an intertidal mudflat and an intertidal sandflat. 


\section{MATERIALS AND METHODS}

Study sites and general sampling description. Two contrasting intertidal environments, a mudflat and a sandflat, were chosen for this study. Both were located near the mouth of the Sheepscot River estuary, Maine, USA, within $5 \mathrm{~min}$ of the laboratory so that samples could be taken in the field but quickly returned to the laboratory for incubation. Salinity in both locations varies little throughout the year since there is little freshwater discharge from the estuary; the range is about 30 to $32 \%$. Water temperature in the estuary ranges between 0 and $20^{\circ} \mathrm{C}$.

Each of the 2 sites was sampled monthly between September 1984 and August 1985. The sampling protocol consisted of measuring sediment organic carbon and nitrogen, bacterial abundance and production, microalgal abundance and production, and sediment oxygen uptake; details of the methods are given below. In addition, I measured meiofaunal abundance and grazing, but those data are to be reported elsewhere. One location was sampled at each site (elevation about $0.6 \mathrm{~m}$ above MLW), being careful to avoid areas utilized the previous month.

Bacterial, microalgal, and organic matter abundance. Sediment samples for sediment pigment and organic matter concentration measurements were taken in duplicate with a $10 \mathrm{~cm}^{3}$ syringe corer to a depth of $2 \mathrm{~cm}$. Standing stock values are reported on either a per volume or per dry weight sediment basis. Values for the upper $2 \mathrm{~cm}$ of sediment may be interconverted using the following factors based on the sediment collected for all the microalgal pigment measure-

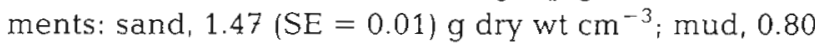
(SE $=0.01) \mathrm{g}$ dry wt $\mathrm{cm}^{-3}$.

Bacterial abundance was determined using DAPI stain and epifluorescence (Porter \& Feig 1980). Subsamples of either $2 \mathrm{~cm}^{3}$ (mud) or $2.5 \mathrm{~cm}^{3}$ (sand) were taken during the bacterial production measurements (see below), preserved in $5 \%$ formalin, and refrigerated until analysis. Those samples were homogenized for 2 min at high speed in a Waring Blender to break up large particles and distribute the bacteria more uniformly on the filters. The dilution used for staining was about 2000 times and the final DAPI concentration was $1 \mu \mathrm{g} \mathrm{ml}^{-1}$ which should minimize problems with the counting procedure (Schallenberg et al. 1989).

Microalgal abundance was estimated by measuring sediment chlorophyll $a$ (chl a) and pheophytin a (pheo a) concentrations. Duplicate analyses were carried out at each site using hexane extraction (Whitney \& Darley 1979) followed by fluorometric analysis; the hexane extraction should eliminate interference from algal pigments other than chl a and pheo a. Algal carbon was estimated assuming a $C$ : chl a ratio of 40 (Cammen \& Walker 1986).

Sediment organic carbon and nitrogen were determined with a Carlos Erba 1106 CHNOS analyzer following vapor-phase acidification with $\mathrm{HCl}$ to remove carbonates (Hedges \& Stern 1984).

Bacterial production. Bacterial production was determined by measuring incorporation of ${ }^{3} \mathrm{H}$-thymidine into DNA and using conversion factors to relate DNA production to production of bacterial cells (Moriarty \& Pollard 1981). Briefly, the procedure was to combine the top $2 \mathrm{~cm}$ of 8 sediment cores $(2.5 \mathrm{~cm}$ diam.), and add either $2 \mathrm{~cm}^{3}$ (mud) or $2.5 \mathrm{~cm}^{3}$ (sand) subsamples to each of a series of $50 \mathrm{ml}$ centrifuge tubes containing various amounts of [methyl- $\left.{ }^{3} \mathrm{H}\right]$-thymidine ( $80 \mathrm{Ci} \mathrm{mmol}^{-1}$ ) and unlabeled thymidine. The initial set of measurements in September 1984 was carried out following the procedure given in Moriarty \& Pollard (1981) with an addition of $5 \mu \mathrm{Ci}{ }^{3} \mathrm{H}$-thymidine to a series of tubes to which $0,2,4,6$, or $8 \mathrm{nmol}$ unlabeled thymidine was also added; there were duplicate tubes for each dilution level as well as a formalin-killed control. Since some of the sand samples had fairly low activity (300 to $500 \mathrm{CPM}$ ) at a relatively high temperature $\left(19^{\circ} \mathrm{C}\right)$, the procedure was changed so that winter samples would still have sufficient activity. Four levels of ${ }^{3} \mathrm{H}$-thymidine additions were used $(0.1,0.5,0.9$, and $1.3 \mathrm{nmol}$, equivalent to $10,40,70$, and $100 \mu \mathrm{Ci}$, respectively), rather than additions of unlabeled thymidine, to give the dilution series; there were duplicate live samples and a formalin-killed control for each of the 4 levels. Enough $0.2 \mu \mathrm{m}$ filtered seawater was added to the isotope solution to bring the total volume added to each tube to $1 \mathrm{ml}$ taking into account the average water content of the upper $2 \mathrm{~cm}$ of sediment $(1.4 \mathrm{ml}$ per $2 \mathrm{~cm}^{3}$ mud sample and $0.9 \mathrm{ml}$ per $2.5 \mathrm{~cm}^{3}$ sand sample), the final concentrations of added ${ }^{3} \mathrm{H}$-thymidine were 0.05 to $0.5 \mu \mathrm{M}$ and 0.13 to $1.3 \mu \mathrm{M}$ for the mud and sand incubations, respectively. Other studies have shown that for incubations lasting up to $5 \mathrm{~h}$, surface sediment slurries gave the same rate of incorporation of ${ }^{3} \mathrm{H}$ thymidine into DNA as intact cores where the radiolabel was introduced by injection to minimize disturbance (Moriarty et al. 1985b, Dobbs et al. 1989. Moriarty \& Pollard 1990). The extraction procedure was based on Moriarty \& Pollard (1982) and Findlay et al. (1984). Samples were incubated in the dark at the in situ temperature (measured $1 \mathrm{~cm}$ deep in the sediment) for 10 to $60 \mathrm{~min}$ (longer incubations for colder temperatures), killed by addition of $5 \mathrm{ml} 0.3 \mathrm{~N} \mathrm{NaOH} / 25$ mM EDTA/0.1\% SDS, autoclaved for $20 \mathrm{~min}$, and centrifuged. DNA (100 $\mu$ g) and humic acid were added to the supernatant to encourage precipitation, the solution was acidified and cooled on ice, the precipitate was collected by centrifugation and rinsed 3 times with 
$3 \mathrm{ml}$ ice-cold $5 \%$ TCA, and then hydrolysed in $3 \mathrm{ml} 5 \%$ TCA at $95^{\circ} \mathrm{C}$ for $30 \mathrm{~min}$. The tubes were then centrifuged, and a subsample of the supernatant was added to scintillation cocktail and assayed with a liquid scintillation counter. Recovery efficiency of DNA was determined by adding [thymine-methyl- ${ }^{3} \mathrm{H}$ ]-DNA to sediment samples and carrying out the extraction procedure; recovery was $89 \%$ in mud and $67 \%$ in the sand, similar to the recovery efficiencies found by Fallon et al. (1983).

In order to calculate the effective dilution of the thymidine for the September 1984 measurements, the non-transformed data were fitted to the original nonlinear equation with $C_{o b s}$ (the activity observed in the DNA) rather than $1 / C_{o b s}$ as the dependent variable (Moriarty \& Pollard 1981) in a manner analogous to Li's (1983) suggestion for analysis of the Michaelis-Menten equation. For the remainder of the production measurements, I also used non-linear regression to fit the data to the following model (modified from Findlay et al. 1984):

$$
C_{\max }=C_{\text {obs }}(L+P) / L
$$

where $C_{\max }=$ the activity that would be observed in DNA if the added ${ }^{3} \mathrm{H}$-thymidine were the only source of intracellular TTP; $L=$ amount of ${ }^{3} \mathrm{H}$-thymidine added to each sample; and $P=$ the unknown 'pool' (endogenous and exogenous) which effectively dilutes the ${ }^{3} \mathrm{H}$ thymidine.

Bacterial production in terms of cells $\mathrm{m}^{-2} \mathrm{~h}^{-1}$ was estimated with a conversion factor of $2 \times 10^{18}$ cells $\mathrm{mol}^{-1}$ thymidine incorporated (Moriarty 1986); production was converted to $\mathrm{mg} \mathrm{C} \mathrm{m}^{-2} \mathrm{~h}^{-1}$ assuming $17 \mathrm{fg} \mathrm{C}$ cell $^{-1}$. The latter factor was derived from the average bacterial cell volume for a Bay of Fundy mudflat, $0.14 \mu^{3}$ (Cammen \& Walker 1986) and a conversion factor of $0.12 \mathrm{~g} \mathrm{C} \mathrm{cm}^{-3}$ (Watson et al. 1977); cell volume in that mudflat did not vary significantly between April and December. The appropriate cell volume: $\mathrm{C}$ conversion factor has been the subject of much discussion (Riemann \& Bell 1990) and the factor used here is lower than another commonly used factor, $0.22 \mathrm{~g} \mathrm{C} \mathrm{cm}^{-3}$ (Bratback \& Dundas 1984); if that factor were to be used, then all bacterial biomass and production values would be increased by $1.8 \times$. The per-cell carbon biomass used here, $17 \mathrm{fg}$, is similar to the value of $20 \mathrm{fg}$ found by Lee \& Fuhrman (1987); those authors found that the carbon biomass per cell remained constant over a range of cell volumes from 0.036 to $0.073 \mu \mathrm{m}^{3}$.

Since the bacterial production incubations were carried out at the temperature during low tide when the sediment was exposed, the rates were adjusted for the temperature of the overlying water to give an estimated rate during submergence. Water temperatures were taken from a nearby monitoring station operated by the Maine Department of Marine Resources and rates during submergence $R_{\text {sub }}$ were calculated from the rates measured during exposure $R_{\exp }$ as

$$
R_{\text {sub }}=R_{\exp } \exp \left[0.07\left(T_{\text {sub }}-T_{\text {exp }}\right)\right]
$$

where $T_{\text {sub }}=$ water temperature; and $T_{\exp }=$ average temperature during the incubations. This expression results in a 2 -fold increase in the rate for a $10^{\circ} \mathrm{C}$ increase in temperature. Temperatures during exposure were assumed to depart significantly from the temperature of the overlying water only when the flats were exposed during the daylight hours. Taking into account the hours of exposure, I then calculated integrated daily rates for bacterial production.

Microalgal production and sediment oxygen uptake. Microalgal production was estimated by measuring oxygen production in sealed plexiglass cores incubated at each of the 2 sites (Hargrave et al. 1983). Core tubes were $15 \mathrm{~cm}$ diameter and $25 \mathrm{~cm}$ long. At each site, 10 core tubes were pushed into the sediment leaving 2 to $3 \mathrm{~cm}$ of the tube exposed. Eight of the tubes were then filled with $0.2 \mu \mathrm{m}$ filtered seawater and 2 of the tubes were filled with a $5 \%$ formalin-seawater mixture to give an estimate of chemical oxygen demand. After the oxygen content of the water within the cores had been measured with a Yellow Springs Instruments portable oxygen meter, the core tubes were sealed with plexiglass tops and Vaseline and the 2 killed control cores and 3 of the others were covered with black tape and foil to keep out light and reduce solar heating during the incubation. The cores were incubated for $1 / 2$ to $1 \frac{1}{2} h$, the dissolved oxygen content measured again, and oxygen flux was calculated. Since light transmittance through the core tubes to the sediment surface was measured as $98 \%$ of incident, no correction for light absorption was felt to be necessary for the original data. Total sediment oxygen uptake was measured by the change in the dark cores that had not been poisoned. Net oxygen production was the change in the light cores. Gross oxygen production was the sum of net production and total uptake in the dark cores without formalin. Chemical oxygen uptake was the change in the cores poisoned with formalin; chemical uptake averaged $33 \%$ (range 28 to $44 \%$ ) for the mudflat and $31 \%$ (range 1 to $78 \%$ ) for the sandflat.

Irradiation was monitored throughout the study with a Climatronics solar sensor. Data was collected routinely as the sum of total illumination in each 15 min interval; during incubations, the resolution was increased to 1 min intervals so that the total irradiance during each incubation could be calculated accurately. For each incubation, photosynthetic efficiency was calculated as $\mathrm{mg} \mathrm{C}$ produced $\mathrm{m}^{-2}$ langley ${ }^{-1}$. In order to predict daily and annual production, it was necessary to account for the exposure time of the sediment surface using tide 
tables (Anonymous 1983, 1984) and the formulae therein to generate tidal heights throughout the day; these heights were then compared to the elevation of the station to predict whether the sediment was exposed or submerged for each of the $15 \mathrm{~min}$ intervals of the light measurements. Light falling during the exposed intervals was summed over the day and multiplied by the photosynthetic efficiency (interpolated between sampling dates) to give estimated daily production. Since sediment oxygen uptake was measured during low tide when the sediment was exposed, the rates were adjusted with the temperature of the overlying water in the same manner as described above for bacterial production to give an estimated rate during submergence; integrated daily sediment oxygen uptake was then calculated. Gross production and sediment oxygen uptake were converted to $\mathrm{g} \mathrm{C} \mathrm{m}^{-2}$ assuming that both the $P Q$ and $R Q$ were 1 (Hargrave et al. 1983).

\section{RESULTS}

\section{Mudflat}

\section{Standing stock measurements}

There was a pronounced seasonal cycle in the abundance of microbes in the sediment, but not in the overall pool of organic carbon (Fig. 1). Both bacteria and chl a concentrations remained fairly constant from fall until late winter when they began a slow decline to the annual minimum in April; a steady increase followed until September. The concentration of pheo a mirrored that of chl $a$, and chl a accounted for 34 to $56 \%$ of the total pigments throughout the year. Microbial carbon accounted for only 1 to $3 \%$ of the sediment organic carbon and of that amount, microalgal carbon made up 61 to $86 \%$.

\section{Microalgal production and sediment oxygen uptake}

There was a marked seasonal cycle in gross oxygen production that was independent of light and the abundance of algal pigments (Fig. 2a); the peak in specific production occurred in June. Temperature appeared to have a strong influence on this parameter with highest values being measured at intermediate temperatures (Fig. 2b); variability was also greatest at the intermediate temperatures. Peak gross production in the mudflat occurred in June and July (Fig. 3). The variability in production due to the $2 \mathrm{wk}$ tidal cycle and the accompanying phase shift in the timing of the low tide periods was also apparent, especially in winter when daylength was shorter.

Sediment oxygen uptake was at a minimum in February, and then increased steadily until fall (Fig. 3);
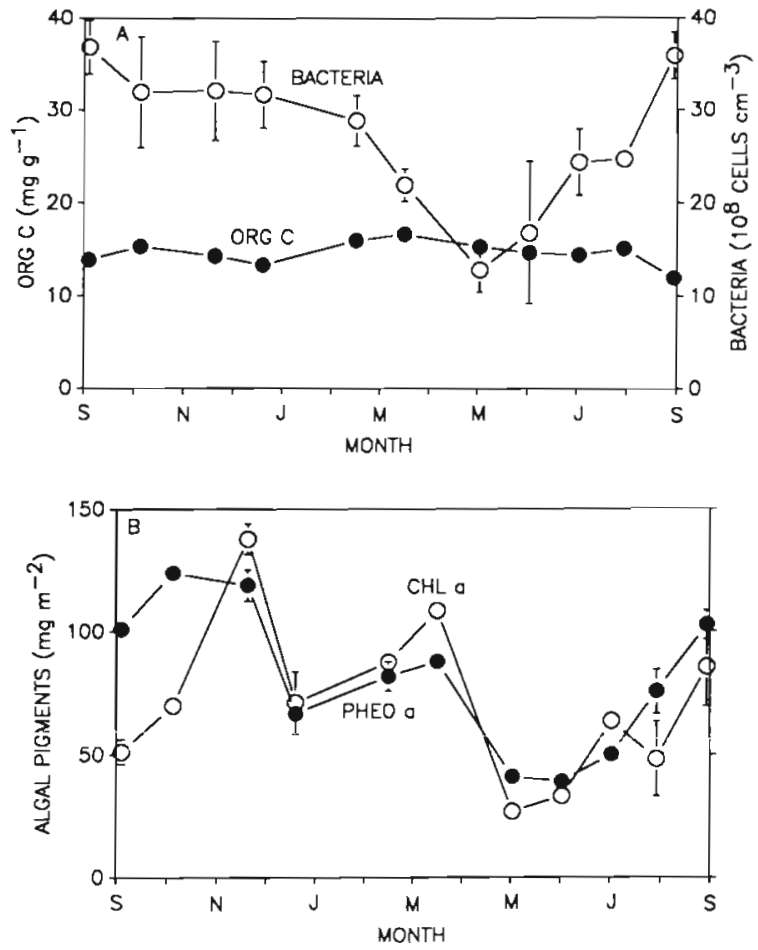

Fig. 1. Standing stocks of bacteria, organic $C_{1}$ and microalgal pigments in the upper $2 \mathrm{~cm}$ of the mudflat sediment. Vertical bars represent \pm 1 standard error; where error bars are not visible, they were smaller than the plotted points
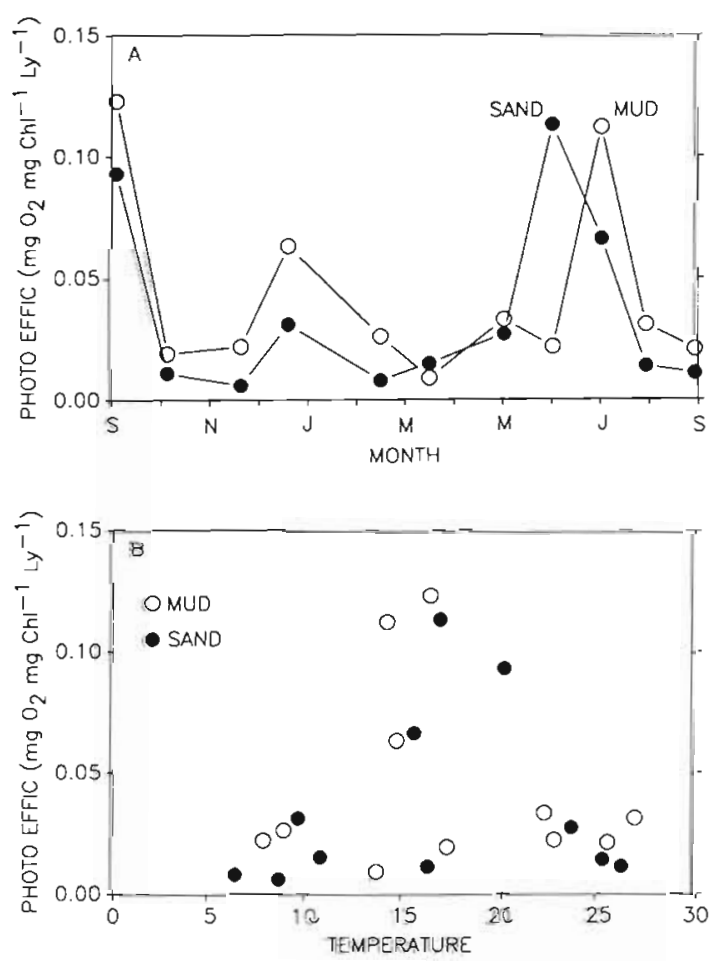

Fig. 2. Photosynthetic efficiency (photosynthesis per unit chl a per unit light) (A) in the mudflat and the sandflat throughout the year, and $(B)$ as a function of temperature 


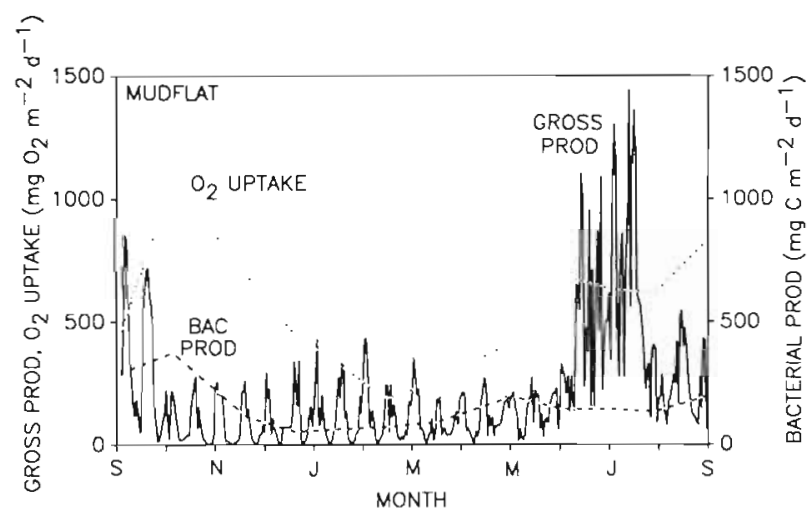

Fig. 3. Annual cycle of gross production, oxygen uptake, and bacterial production in the mudflat sediments. Measurements were carried out while the sediment was exposed and have been corrected for water temperature and light reaching the sediment surface between sampling dates

after October the oxygen uptake rate declined fairly steadily until reaching the winter minimum. There was no obvious response to the peak in microalgal production in June and July and the correlation between gross production and sediment oxygen uptake throughout the year was not significant $(r=0.37 ; n=11 ; p<0.26)$.

\section{Bacterial production}

Bacterial productivity varied seasonally in the mudflat with rates being highest in the fall and lowest during the winter and early spring (Fig. 3). The rate approximately doubled between March and April and remained at an elevated level throughout the summer. Turnover times for the bacterial population in the upper $2 \mathrm{~cm}$ of the mudflat ranged from $2.2 \mathrm{~d}$ in April when the spring peak in productivity coincided with the annual minimum in standing stock to $21 \mathrm{~d}$ in December when production was minimal (Fig. 4).

\section{Sandflat}

Standing stock measurements

The seasonal cycle in microalgal pigments was similar to that seen in the mudflat, but bacterial abundance did not appear to vary seasonally (Fig. 5). Chl a concentrations remained about $100 \mathrm{mg} \mathrm{m}^{-2}$ throughout most of the year, but decreased by half from April to June; chl a accounted for 55 to $80 \%$ of the total microalgal pigments. Pheo a declined steadily from September to December, remained fairly constant until May and increased steadily throughout the summer. Microbial carbon accounted for 2 to $7 \%$ of sediment organic carbon and of that amount, microalgal carbon made up 88 to $96 \%$.
Microalgal production and sediment oxygen uptake

The spring peak in specific gross production occurred in May, 1 mo prior to the peak value in the mudflat (Fig. 2a); intermediate temperatures gave the maximum specific productivity rates (Fig. 2b), again similar to what was found for the mudflat. Microalgal gross production in the sandflat system peaked in late May and early June (Fig. 6). Productivity was relatively low during the remainder of the year with the exception of the initial sampling period in early September. As with the mudflat system, the variability due to the $2 \mathrm{wk}$ tidal cycle was apparent and was greatest during winter.

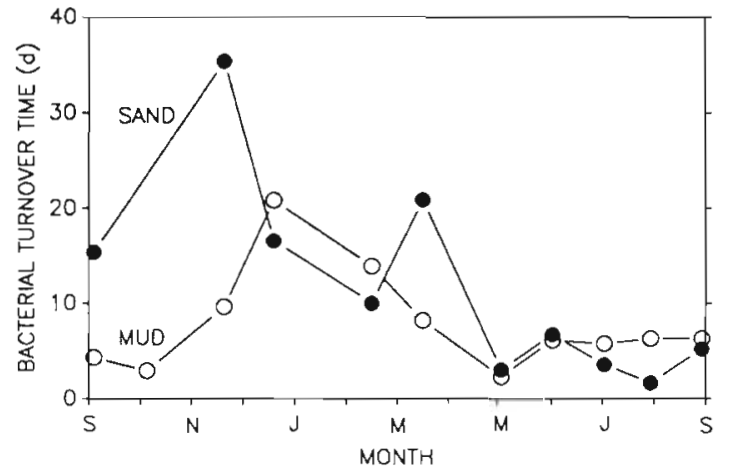

Fig. 4. Bacterial turnover time in the mudflat and sandflat sediments
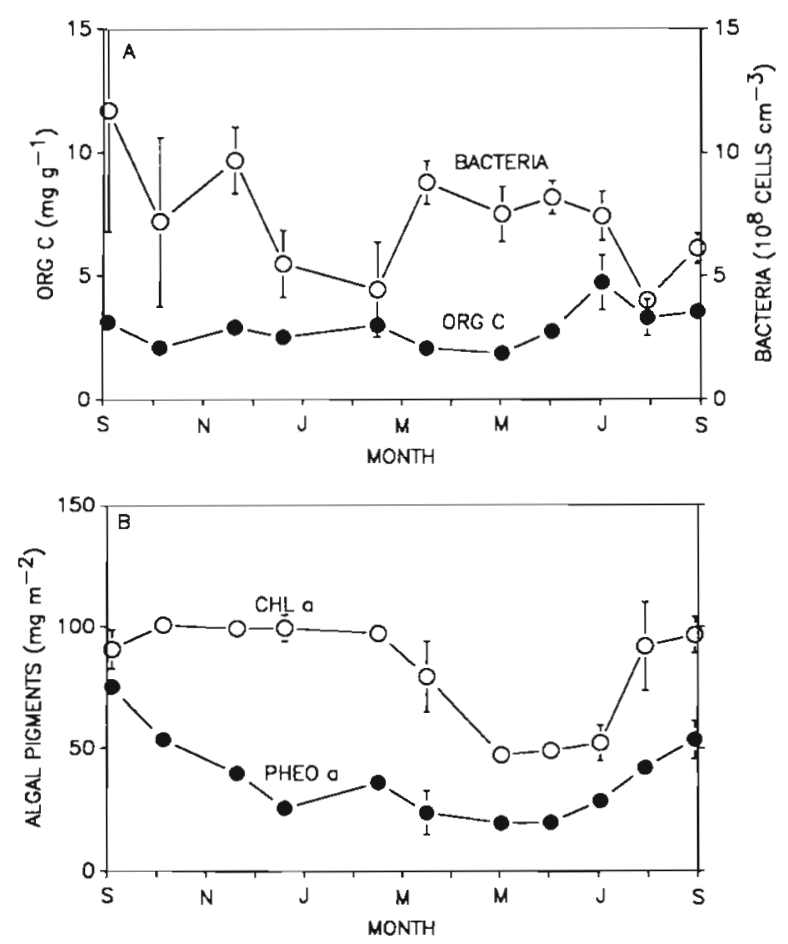

Fig. 5. Standing stocks of bacteria, organic C, and microalgal pigments in the upper $2 \mathrm{~cm}$ of the sandflat sediment. Vertical bars represent \pm 1 standard error; where error bars are not visible, they were smaller than the plotted points 


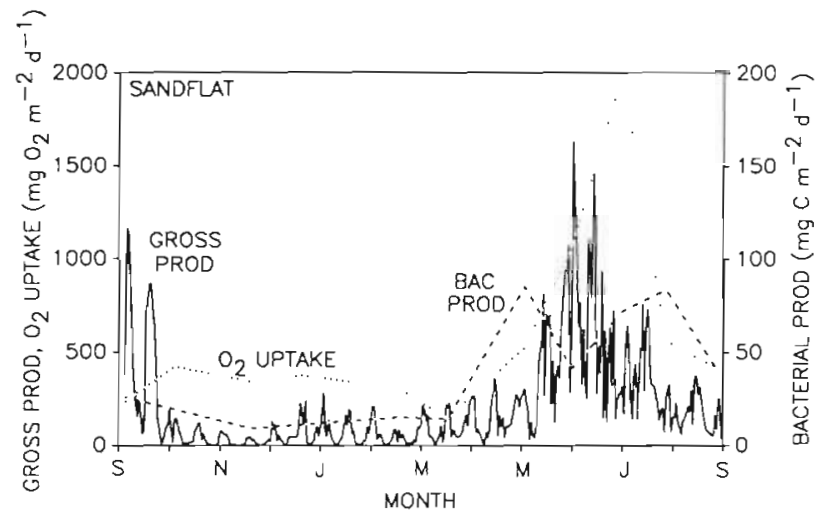

Fig. 6. Annual cycle of gross production, oxygen uptake, and bacterial production in the sandflat sediments. Measurements were carried out while the sediment was exposed and have been corrected for water temperature and light reaching the sediment surface between sampling dates

Sediment oxygen uptake peaked markedly just following the peak in microalgal productivity (Fig. 6). The oxygen uptake rate remained relatively low during the remainder of the year. There was a strong correlation between gross production and sediment oxygen uptake throughout the year $(\mathrm{r}=0.91 ; \mathrm{n}=11 ; \mathrm{p}<0.01)$.

\section{Bacterial production}

There was a strong seasonal response in bacterial productivity in the sandflat with a 6-fold increase between March and April (Fig. 6). Productivity remained at a high level throughout the summer. Turnover times for the bacterial population in the upper $2 \mathrm{~cm}$ of the sediment ranged from a minimum of $2 \mathrm{~d}$ in July to a maximum of $36 \mathrm{~d}$ in November (Fig. 4).

\section{Annual carbon budgets for the mudflat and sandflat}

The monthly values of bacterial production and sediment community oxygen uptake were integrated between samples and compared to the sum of the daily predicted gross production rates (Table 1). The annual totals of gross production and community oxygen

Table 1. Estimated annual totals of gross production, oxygen uptake, and bacterial production for the sediment community of the mudflat and sand flat stations. $P Q$ and $R Q$ have been assumed to be 1 . All values are given as $\mathrm{g} \mathrm{C} \mathrm{m}^{-2} \mathrm{yr}^{-1}$

\begin{tabular}{|lcc|} 
& Mudflat & Sandflat \\
\hline Gross production & 29 & 28 \\
Sediment oxygen uptake & 76 & 76 \\
Bacterial production & 56 & 13 \\
\hline
\end{tabular}

uptake were similar for the mudflat and sandflat stations and at each location in situ production by microalgae was apparently not enough to provide the organic carbon respired by the sediment community; there was a deficit of 46 to $47 \mathrm{~g} \mathrm{C} \mathrm{m}^{-2}$ (equivalent to 62 to $63 \%$ of the community respiration). Estimated bacterial production at the mudflat station was 4.3 times that of the sandflat station.

\section{Relationship between bacterial production and other parameters}

Gross production was correlated with bacterial production for the sandflat ( $\mathrm{r}=0.74 ; \mathrm{n}=10 ; \mathrm{p}<0.02)$, but not for the mudflat $(r=0.09 ; n=11 ; p<0.81$ ) (Fig. 7). During the spring-summer period from April to August, bacterial production was not significantly correlated with gross production for either the mudflat $(\mathrm{r}=-0.73$; $\mathrm{n}=5 ; \mathrm{p}<0.17)$ or the sandflat $(\mathrm{r}=0.53 ; \mathrm{n}=5$; $\mathrm{p}<0.36$ )

Bacterial production and sediment oxygen uptake were also correlated for the sandflat throughout the year, but not for the mudflat (Fig. 8); correlation coefficients were $r=0.43(n=11 ; p<0.19)$ for the mudflat

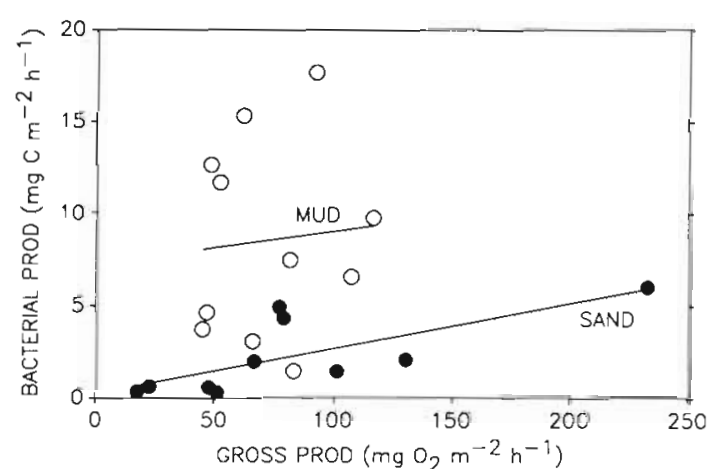

Fig. 7. Relationship between bacterial production and gross production for the mudflat and sandflat sediments. See text for description of regression lines

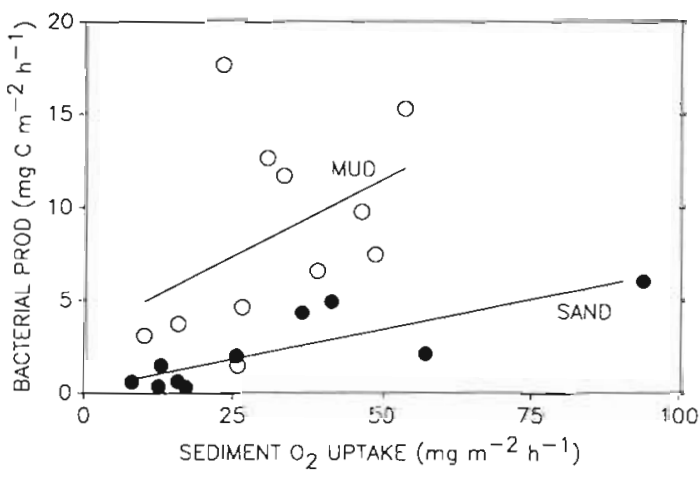

Fig. 8. Relationship between bacterial production and oxygen uptake for the mudflat and sandflat sediments. See text for description of regression lines 
and $r=0.82(n=10 ; p<0.01$ ) for the sandflat. During the April to August period, bacterial production was not significantly correlated with sediment oxygen uptake in either the sandflat $(r=0.60 ; n=5 ; p<0.29)$ or the mudflat $(r=-0.70 ; n=5 ; p<0.20)$.

The turnover time of the bacteria decreased with increasing temperature and the relationship was similar for both the mudflat and the sandflat (Fig. 9a). However, it appeared that there was little further decrease in turnover time once the temperature reached about $15^{\circ} \mathrm{C}$. In order to quantify the relationship, the natural $\log$ of $\mu$, the specific growth rate of the bacteria (and the inverse of the turnover time), was plotted on an Arrhenius plot as a function of the inverse of the temperature in K (Fig. 9b). The slope of the curve is $-E_{\mathrm{a}} / R$ where $E_{\mathrm{a}}$ is the activation energy and $R$ is the gas constant; higher values of $E_{a}$ indicate increased temperature sensitivity. $E_{a}$ calculated from just the measurements at temperatures $<19^{\circ} \mathrm{C}$ was $22.1 \mathrm{kcal}$ $\mathrm{mol}^{-1}\left(\mathrm{SE}=5.5, \mathrm{n}=13, \mathrm{r}^{2}=0.60, \mathrm{p}<0.01\right) ; E_{\mathrm{a}}$ for all temperatures was $14.6 \mathrm{kcal} \mathrm{mol}^{-1}$ ( $\mathrm{SE}=3.1, \mathrm{n}=21$, $r^{2}=0.54, p<0.01$ ) indicating a reduced sensitivity to temperature changes at higher temperatures.

Finally, stepwise multiple regressions were calculated for each of the flats relating bacterial specific growth rate during exposure $\left(\mu, \mathrm{d}^{-1}\right)$ to several potentially important parameters including the inverse of
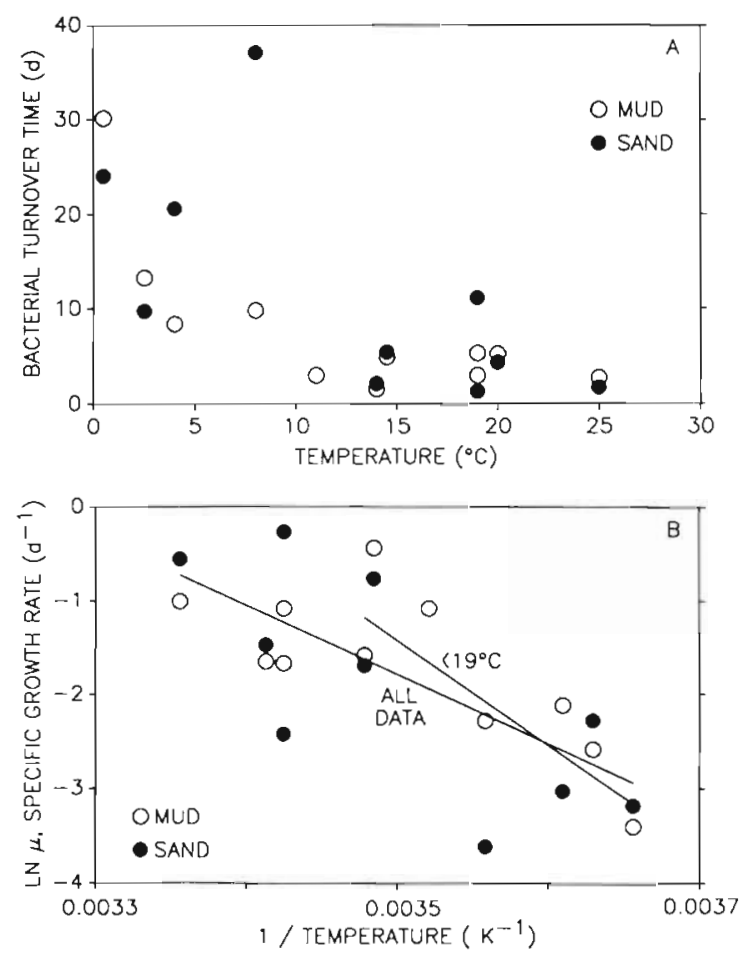

Fig. 9. Relationship between bacterial growth rate and temperature for the mudflat and sandflat sediments. (A) Bacterial turnover time as a function of temperature. (B) Arrhenius plot of specific growth rate $\mu$ as a function of temperature (see text for description of regression lines) temperature during the incubations $\left(1 / T, \mathrm{~K}^{-1}\right)$, gross production measured during exposure $\left(P, \mathrm{mg} \mathrm{O} \mathrm{O}_{2} \mathrm{~m}^{-2}\right.$ $\left.\mathrm{h}^{-1}\right)$, algal biomass $\left(A, \mathrm{mg} \mathrm{chl} a \mathrm{~m}^{-2}\right)$, and bacterial biomass $\left(B, \mathrm{mg} \mathrm{C} \mathrm{m}^{-2}\right)$. Sediment oxygen uptake was not included in the regression since it is partially a function of bacterial activity and thus could not be considered an independent variable. For the mudflat, only the temperature term was significant; the calculated regression equation was:

$$
\begin{gathered}
\text { Ln } \mu=20.71-6399(1 / T) \\
\left(\mathrm{r}^{2}=0.57, \mathrm{n}=11, \mathrm{p}<0.01\right)
\end{gathered}
$$

For the sandflat, the temperature term alone had an $r^{2}$ of 0.55 , the addition of bacterial biomass raised $R^{2}$ to 0.83 , and the addition of algal biomass raised $R^{2}$ to 0.94 ; all 3 terms were significant and the calculated regression equation was:

$$
\begin{gathered}
\operatorname{Ln} \mu=29.17-7845(1 / T)-0.01922 A-0.008268 B \\
\left(\mathrm{R}^{2}=0.94, \mathrm{n}=10, \mathrm{p}<0.01\right)
\end{gathered}
$$

The ratio of bacterial production to sediment oxygen uptake was also very similar between the mudflat and sandflat systems for most of the year (Fig. 10). The ratio was low in the winter and rose to a peak value in March-April for both systems as bacterial production increased more quickly than sediment oxygen uptake. The systems also behaved similarly from March to June with the ratio declining sharply. Only after June did the response of the 2 systems diverge; the ratio in the mudflat remained constant throughout the summer and then peaked in September, while the ratio in the sandflat increased to a peak value in August. The ratio of the annual totals of bacterial production to community respiration was 0.74 for the mudflat and 0.17 for the sandflat.

\section{DISCUSSION}

The original intention of this study was to choose 2 different environments, a sandflat and a mudflat, that

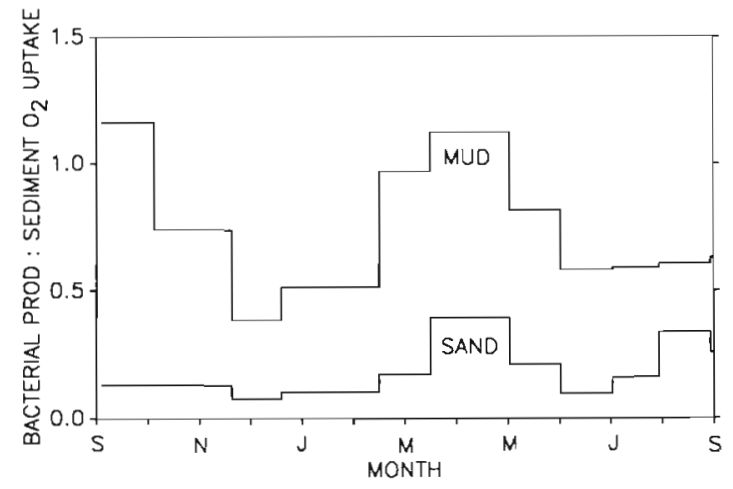

Fig. 10. Ratio of bacterial production to oxygen uptake for the mudflat and sandflat sediments. Values are averages of consecutive sampling dates 
would include a wide range of primary production and community respiration values with which to compare bacterial production; however, carbon flow through the 2 flats was similar (Table 1). It is not surprising that gross production would be similar since the light and temperature regimes were essentially identical and chl a concentrations in the upper $2 \mathrm{~cm}$ of the sediment from the 2 areas were comparable throughout the year (Figs. 1 \& 5). Although the spring peak in production occurred 1 mo later in the mudflat than in the sandflat, the magnitude was comparable. Given that the flats were sampled only monthly, with the possibility of any particular date giving atypical data, the overall comparability in production was striking.

The similarity of annual total sediment oxygen uptake was somewhat misleading since the seasonal cycle differed markedly between the 2 areas. Peak sediment oxygen uptake in the sandflat occurred immediately following the gross production peak, and within $2 \mathrm{mo}$, the enhanced oxygen uptake disappeared. In the mudflat, sediment oxygen uptake also increased following the spring peak in gross productivity, but that increase was much less dramatic and in fact was part of a steady increase that began in February. Sediment oxygen uptake in the mudflat was greatest in the fall, but there was no indication of a similar peak in the sandflat. In a study of a Bay of Fundy mudflat, community respiration also did not respond to the spring benthic microalgal bloom, but instead reached a maximum in late August or early September at about the same time as a late summer peak in microalgal production (Hargrave et al. 1983).

There was a closer coupling between algal production, sediment oxygen uptake, and bacterial productivity in the sandflat than in the mudflat and that may have been due to the more dynamic nature of the sandflat. The average organic $C$ content of the upper $2 \mathrm{~cm}$ of the sandflat, $86 \mathrm{~g} \mathrm{C} \mathrm{m}^{-2}$, was about equivalent to one year's oxygen uptake; in contrast, the standing stock of organic $C$ in the upper $2 \mathrm{~cm}$ of the mudflat, $222 \mathrm{~g} \mathrm{C} \mathrm{m}^{-2}$, was equivalent to about 3 years' oxygen uptake. Of course some of the measured oxygen uptake would actually have been due to decomposition of organic matter in deeper layers of the sediment, but the average 'chemical' uptake of oxygen was similar for both areas. Additional evidence of the more dynamic nature of the sandflat was the observation that although most of the algal production occurred in a distinct spring pulse in both systems, only in the sandflat was there an obvious response in community oxygen uptake; the mudflat sediment community responded much more slowly and tended to integrate the response over the entire year. Again, as might be expected given the faster turnover time of organic matter in the sandflat, seasonal variability in bacterial production was more closely coupled to both algal production and sediment community respiration in the sandflat than in the mudflat.

Gross production values were in the low end of the range reported by Colijn \& de Jonge (1984) for intertidal flats and shallow coastal sediments, while sediment oxygen uptake values were comparable to those from other studies (van Es \& Meyer-Reil 1982, Hargrave et al. 1983). It is possible that production was reduced during the primary production incubations due to downward migration of the microalgae after water was added to the cores (Holmes \& Mahall 1982). In addition, production was assumed to be negligible during submersion of the flats, but this may not always be the case, even with depths of $2 \mathrm{~m}$ at high tide (Leach 1970, Varela \& Penas 1985). A third potential problem arose from the need to extrapolate gross production between sampling dates (Colijn \& de Jonge 1984, Shaffer \& Onuf 1985, Lamontagne et al. 1989). The assumption made in this study was that productivity was never light-saturated; therefore, productivity on days between actual measurements was predicted from measured oxygen production per unit light and light available to the microalgae. Previous studies of the relation between photosynthesis and light have given contradictory results with some indicating light-saturation at ambient levels, and others finding a linear relationship between primary production and light (Hargrave et al. 1983 and references therein). As Shaffer \& Onuf (1985) pointed out, the discrepancy may be partially due to some investigators (those observing light saturation) having measured actual saturation, while other investigators measured ecological saturation; the ecological saturation level is the light intensity necessary to saturate the entire integrated population of photosynthesizing microalgae in the sediment column, extending to a depth that may reach several millimeters (Taylor 1964, Gomoiu 1967, Fenchel \& Straarup 1971). While microalgae at the sediment surface may well exhibit photosynthetic saturation, those below the immediate surface will be subject to reduced light intensity and the result may be that community production, taken as whole, is not light-saturated.

To assess the scale of the problem, gross production was recalculated assuming: (1) that the hourly production rates measured in the middle of the day continued during the entire period of exposure; and (2) that the daily rates could be interpolated between samples without regard for variability in available light due to weather or the shifting of exposure time during the day with tidal phase. The resulting estimates for annual gross algal production were $38 \mathrm{~g} \mathrm{C} \mathrm{m}^{-2}$ for the mudflat and $39 \mathrm{~g} \mathrm{C} \mathrm{m}^{-2}$ for the sandflat, increases of 31 and $38 \%$ respectively over the values of gross production calculated assuming light limitation. 
To calculate the carbon budgets presented in Table 1 , it was necessary to assume values for the $R Q$ and $P Q$ of the sediment community. A wide range of measured and assumed values can be found in the literature for each of these, but the most commonly assumed values are either 1 for both $P Q$ and $R Q$ or 0.85 for $R Q$ (Hargrave 1973) and 1.2 for $P Q$ (Ryther 1965). If an RQ of 0.85 and a PQ of 1.2 had been used in this study, then calculated annual gross production would have been 34 and $33 \mathrm{~g} \mathrm{C} \mathrm{m}^{-2}$, for the mudflat and sandflat, respectively; annual oxygen uptake would have been 65 and $64 \mathrm{~g} \mathrm{C} \mathrm{m}^{-2}$ for the mudflat and sandflat. The result would have been a deficit of production compared to respiration of $31 \mathrm{~g} \mathrm{C} \mathrm{m}^{-2}$ for both areas. Similar disagreement exists as to the appropriate conversion factor relating cell volume to organic carbon content (Riemann \& Bell 1990); if the other commonly used factor of $0.22 \mathrm{~g} \mathrm{C} \mathrm{m}^{-3}$ (Bratback \& Dundas 1984) had been used, annual bacterial production would have been calculated as 102 and $24 \mathrm{~g} \mathrm{C} \mathrm{m}^{-2}$ for the mudflat and the sandflat, respectively.

The estimated turnover times for the bacteria in the upper $2 \mathrm{~cm}$ of sediment were comparable during much of the year for the sandflat and mudflat systems (Fig. 4). Only in the fall, when bacterial productivity was relatively high in the mudflat but not in the sandflat, was there a large difference. During spring and summer (April to August), turnover times averaged 4 to $5 \mathrm{~d}$ for both areas. Turnover time for the sandflat bacteria decreased from 7 to $2 \mathrm{~d}$ in the 2 mo following the spring algal production peak, but no response was apparent for bacteria in the mudflat, again showing the more dynamic nature of the sandflat system at this time. Based on the average mean bacterial biomass during the year and the annual bacterial production, the mudflat bacterial population would have turned over 59 times during the year and the sandflat bacterial population 52 times.

The estimated rates of bacterial production from this study were within a factor of 2.2 of the rates predicted by Cole et al. (1988) from the mean sediment organic content and fell within the range of values for marine and fresh water sediments reviewed by van Duyl \& Kop (1990). For the mudflat, the rate calculated from the regression equation in Cole et al. (1988) was equivalent to $70 \mathrm{mg} \mathrm{C} \mathrm{m}^{-2} \mathrm{~d}^{-1}$ (after correction for the sediment density of the mud); the daily mean rate from this study was $154 \mathrm{mg} \mathrm{C} \mathrm{m}^{-2}$. For the sandflat, the calculated rate was equivalent to $44 \mathrm{mg} \mathrm{C} \mathrm{m}{ }^{-2} \mathrm{~d}^{-1}$ while the measured daily mean rate was $36 \mathrm{mg} \mathrm{C} \mathrm{m}^{-2}$.

Both bacterial production and specific growth rate were lower for the sandflat in this study than for 3 other temperate sandflats recently investigated in the Netherlands (van Duyl \& Kop 1990). In order to make the comparisons, it was first necessary to correct for some differences between the 2 studies: (1) The previous study used a conversion factor of $1 \times 10^{18}$ bacterial cells produced $\mathrm{mol}^{-1}$ thymidine incorporated; I used $2 \times 10^{18}$. (2) The average biomass of a bacterial cell in that study was $30 \mathrm{fg} \mathrm{C}_{i}$ I used $17 \mathrm{fg} \mathrm{C}$ in this study. (3) There was no correction for the recovery efficiency of DNA during the measurements in the previous study; in this study, the recovery efficiency in sand was $89 \%$. Considering all those factors together, and assuming the recovery efficiency for DNA would have been similar, the Dutch bacterial production values were made comparable to those reported here by multiplying by $\left(2 \times 10^{18} / 1 \times 10^{18}\right) \cdot(17 / 30) \cdot(1 / 0.89)$ or 1.27 ; since cell biomass does not enter into the calculation of specific growth rate, that correction factor was 2.25. For the 3 Dutch sandflats, corrected bacterial production for the upper $3 \mathrm{~mm}$ of sediment averaged 38,42 , and $495 \mathrm{mg} \mathrm{C}$ $\mathrm{m}^{-2} \mathrm{~d}^{-1}$; average bacterial production for the upper $2 \mathrm{~cm}$ of sediment for the sandflat in this study was $36 \mathrm{mg} \mathrm{C} \mathrm{m} \mathrm{d}^{-1}$. For the Dutch sandflats, average corrected values of $\mu$ from March through September (calculated by estimating biomass values from their Fig. 5) were $0.63,1.19$, and $8.06 \mathrm{~d}^{-1}$; average $\mu$ during March through August for the sandflat in this study was 0.44 .

The difference in $\mu$ between the Dutch sandflats and the sandflat from this study was predictable since bacterial populations in the upper $3 \mathrm{~mm}$ of sediment would be expected to be more active than deeper populations. It is not clear, however, why the bacterial production rates were higher in the Dutch sandflats, especially considering that the rates included only the upper $3 \mathrm{~mm}$ and presumably would have been much higher if the entire $2 \mathrm{~cm}$ sediment column had been included (van Duyl \& Kop 1990). The range in sediment temperature was similar in both studies and $C$ mineralization rates were within a factor of 2.5 for all 4 sandflats, but the range in bacterial production rates was almost 2 orders of magnitude; even within the Dutch study, the range was $13 \times$, van Duyl \& Kop (1990) explained the differences as a response to variable supplies of organic matter, but if that hypothesis is correct, then the question of how a 2-fold difference in organic supply produced a 13-fold difference in bacterial production is certainly intriguing.

In a previous study of a Bay of Fundy mudflat, bacterial abundance per unit organic carbon was found to be closely related to microalgal biomass but not to microalgal production during the sampling period of April to December (Cammen \& Walker 1986). In particular, of the 2 microalgal blooms that occurred in the mudflat (Hargrave et al. 1983), one in June and one in September, only the fall bloom was accompanied by an increase in microalgal biomass and it was only during the fall bloom that bacterial abundance per g organic 
$C$ responded. In addition, a comparison of sediment taken during a period of low microalgal abundance with sediment taken just after the microalgal bloom showed that there was a strong correlation between the increases in microalgal and bacterial abundances among the various size-fractions. The hypothesis was put forth that the relationship was due to the release of extracellular material by the microalgae. Although a similar relationship between bacterial biomass per unit organic carbon and algal biomass was present from April through August in the mudflat data from this study (Fig. 1; $\mathrm{r}=0.95 ; \mathrm{n}=5 ; \mathrm{p}<0.02$ ), no such relationship was apparent in the sandflat data during the same period (Fig. $5 ; \mathrm{r}=-0.71 ; \mathrm{n}=5 ; \mathrm{p}<0.16$ ) Bacterial production from April to August was also not significantly related to microalgal biomass in either the mudflat or the sandflat.

The difference in sampling methods between the 2 studies may have been responsible for the inconsistent results. The microalgae, bacteria and organic carbon samples from the Bay of Fundy study were taken by gently scraping the sediment surface with a spatula to a depth of a few millimeters. The comparable samples from this study were taken with syringe corers to a depth of $2 \mathrm{~cm}$. Since microalgal biomass is concentrated near the sediment surface (Joint et al. 1982 Varela \& Penas 1985), taking deeper cores may have obscured any relationship that might have been present. The fact that increases of algal and bacterial biomass within one size fraction of sediment particles are not necessarily reflected in other size fractions (Cammen \& Walker 1986) shows the close spatial coupling of the bacteria and the microalgae and serves to emphasize that if the nature of their relationship is to be examined in detail, the investigations need to be carried out on an appropriately small scale.

The parameters measured in this study fell into 2 groups based on the similarity between their annual totals or mean abundances for the mudflat and for the sandflat. Those essentially the same for the 2 areas included (with the ratio of the mudflat value to the sandflat value in parentheses): microalgal biomass (0.9), gross production (1.0), and sediment oxygen uptake (1.0). The remaining parameters differed to about the same extent between the 2 areas and included: bacterial biomass $(3.8)$, bacterial production (4.3), and sediment organic carbon (4.7). Judging solely on the basis of the annual data, it would appear that bacterial biomass and production were uncoupled from both primary production and respiration of the other sediment organisms in the 2 systems; however, previous investigators using fine-scale temporal sampling have been able to show diel variability in bacterial productivity that was correlated with photosynthetic activity of seagrasses and microalgae (Moriarty \& Pol- lard 1982, Moriarty et al. 1985a). The similarity in turnover times for the bacterial populations of the mudflat and sandflat (Fig. 4) throughout much of the year suggests a commonality in the factors controlling bacterial dynamics in both environments.

It is clear that temperature is the factor that had the major influence on bacterial production in this study. Temperature alone explained 55 to $57 \%$ of the variation in specific growth rate of the bacteria during the entire year. The stepwise regression analysis showed that the bacteria were less affected by microalgal production or biomass than they were by temperature. As discussed above, that may be partly the result of the different vertical distributions of the bacteria and the microalgae; in particular microalgal production would certainly be concentrated at the sediment surface. The importance of temperature as a control of sediment bacterial growth and activity is supported by previous results from the water column (e.g. Li \& Dickie 1987) and from intertidal sediment (Mayer 1989), but contrasts with results of a study of a shallow-water station in Kiel Bight where bacterial activity was apparently as high in the winter as in the early fall (Meyer-Reil 1987). However, since the bacterial activities reported in the Kiel Bight study were not normalized to bacterial abundance, which also increases in the winter (MeyerReil 1983), it is not possible to be sure that specific activity actually was higher; the results could also be explained by an increase in the abundance of bacteria with the same (or lower) specific activity. In addition, the uptake of radiolabeled compounds was measured without knowing their specific activities in the sediment so that the results might also have been due to decreased pool sizes in the winter resulting in increased specific activity. The intertidal proteolytic enzymatic activity results reported by Mayer (1989) were also standardized to sediment volume rather than bacterial abundance, and thus do not necessarily reflect specific activity of the bacteria. Results from 3 Dutch sandflats were variable with a marked relationship between temperature and bacterial productivity present in one flat, but not the other two (van Duyl \& Kop 1990); those authors hypothesized that temperature was important only where nutrient limitation was not a factor. However, although values of $\mu$ in this study were lower than those seen in the Dutch study, there was still a strong relationship with temperature.

Bacteria apparently responded to the increase in temperature in late winter-early spring more quickly than the rest of the community as evidenced by the increase in the ratio of bacterial production: sediment oxygen uptake (Fig. 10). In addition to the temperature increase, this is the time when input from the spring plankton bloom should be maximal (Townsend \& Cammen 1988). If this observation is correct, the ability of 
the bacterial community to function relatively better at low temperatures than the larger organisms in the sediment could mean that a greater proportion of organic matter would flow through the bacteria at lower temperatures. This, in turn, would imply that the input of organic matter to the benthos from an early spring bloom, occurring in colder waters, might result in a less efficient transfer of energy to the macrofauna. The effect of the temperature of the water during and following early spring blooms has been examined previously (Pomeroy \& Deibel 1986, Townsend \& Cammen 1988) and it has been suggested that colder temperatures will favor delivery of fresh organic material to the benthos which should result in increased benthic productivity; however, the results from this study also suggest the possibility that the proportion of that benthic productivity due to macrofauna may be lower in colder water.

In this study, the specific growth rate of the bacteria $\mu$ was used to investigate the influence of various factors on bacterial productivity. As discussed above, previous investigators have often used measures of total bacterial activity standardized only to weight or volume of sediment (e.g. Meyer-Reil 1983, Mayer 1989, van Duyl \& Kop 1990) to carry out similar analyses. While those analyses are certainly useful, they do not reveal as much of the 'physiological' response of bacteria to certain factors as they reveal of the 'ecological' response. Specific growth rate (or activity) depends only on the physiological state of the bacteria; total bacterial productivity (or activity), on the other hand, is a function not only of $\mu$ but also of bacterial abundance. Since there are any number of independent controls on bacterial abundance which may covary with temperature (for example, grazing), the response to temperature may be masked. As an example, one could imagine that in the fall, specific growth rate of the bacteria would decrease as water temperatures began to fall; if protozoan grazers happened to be more sensitive than the bacteria to the decrease in temperature, then grazing would decline relative to production, bacterial biomass might increase, and the relative decrease in specific growth rate of the bacteria would therefore be greater than the relative decrease in total productivity. Thus, if the object is to investigate the effects of various environmental parameters on bacterial populations, bacterial production or activity should first be expressed on a cell-specific or biomassspecific basis. Even then, however, it is not possible to distinguish variation in cell-specific activity from variation in the proportion of active cells without autoradiographic (or other similar) data.

A final point that needs to be addressed is the meaning of bacterial production within the ecosystem. It is common in the literature to find that the authors have measured bacterial production, assumed a growth efficiency, and calculated the 'demand' of the bacteria on the ecosystem for organic carbon or energy. As has been discussed previously (Strayer 1988), that calculation is likely to be incorrect; however, since the error continues to appear in the literature, a brief discussion is included here. In much the same way we think of phytoplankton production, we can consider bacterial production to be either 'new' or 'recycled'. 'New' bacterial production is based on organic matter produced in situ by phytoplankton or benthic algae; in the case of sediment bacteria, 'new' production could also be based on organic matter newly input to the benthos through sedimentation or direct uptake from the overlying water. 'Recycled' production occurs as pools of detrital organic matter are transformed to bacterial biomass. The distinction becomes important when we try to construct a carbon budget for the sediment community and need to decide whether or not the bacterial production we have measured actually represents a demand for organic matter in addition to that produced by the microalgae.

Consider for example, an annual microalgal production of $100 \mathrm{~g} \mathrm{C}$ processed entirely by bacteria with a $50 \%$ growth efficiency. As the material is metabolized initially by the bacteria, $50 \mathrm{~g} \mathrm{C}$ is respired and $50 \mathrm{~g} \mathrm{C}$ is converted to bacterial biomass. If all those bacteria eventually die and are in turn processed by other bacteria, the result will be an additional $25 \mathrm{~g} C$ respired and $25 \mathrm{~g} \mathrm{C}$ bacterial production. If the process continues, eventually the initial input of $100 \mathrm{~g} \mathrm{C}$ microalgal production will have generated $100 \mathrm{~g} \mathrm{C}$ bacterial respiration and $100 \mathrm{~g} \mathrm{C}$ bacterial production. Given those data, we might conclude erroneously that the system required an import of $100 \mathrm{~g} \mathrm{C}$ in addition to the $100 \mathrm{~g} \mathrm{C}$ microalgal production just to support the bacteria. The example is oversimplified, of course, but emphasizes the necessity for caution in using bacterial production measurements to estimate the demand on primary production (or input from sedimentation) and the potential for providing organic matter to consumers. In fact, it is quite possible that a high percentage of the bacterial production measured in this study might actually have been supported by recycling of the in situ microalgal production and as such would not have required an introduction of additional organic matter to the system. The degree of recycling will vary with each particular location, but to my knowledge no one has yet determined a reliable figure for even one benthic (or pelagic) system.

Acknowledgements. Elizabeth Langton assisted with all phases of the field work and laboratory measurements. CHN analyses were carried out by Linda Shick (University of Maine). This manuscript was written at the Institute of Ecol- 
ogy and Genetics, Aarhus University, Denmark, and the support of the staff is gratefully acknowledged. Comments of anonymous reviewers were also helpful. The study was supported by NSF grants EXP80-11448, OCE-83-09406, and OCE-85-11281. This is Bigelow Laboratory for Ocean Sciences Contribution No. 91-002.

\section{LITERATURE CITED}

Anonymous (1983). Tide tables for 1984. East coast of North and South America. U.S. Dept. of Commerce, NOAA, National Ocean Service. U.S. Government Printing Office, Washington, D.C.

Anonymous (1984). Tide tables for 1985. East coast of North and South America. U.S. Dept. of Commerce, NOAA, National Ocean Service. U.S. Government Printing Office, Washington, D.C.

Bratback, G., Dundas, I. (1984). Bacterial dry matter content and biomass estimations. Appl. environ. Microbiol. 48: 755-757

Cammen, L. M. (1989). The relationship between ingestion rate of deposit feeders and sediment nutritional value. In: Lopez, G., Taghon, G., Levinton, J. (eds.) Ecology of marine deposit feeders. Springer-Verlag, New York, p. 201-222

Cammen, L. M., Walker, J. A. (1986). The relationship between bacteria and micro-algae in the sediment of a Bay of Fundy mudflat. Estuar. coast. Shelf Sci. 22: 91-99

Cole, J. J., Findlay, S., Pace, M. L. (1988). Bacterial production in fresh and saltwater ecosystems: a cross-system overview. Mar. Ecol. Prog. Ser. 43: 1-10

Colijn, F., de Jonge, V. N. (1984). Primary production of phytobenthos in the Ems-Dollard estuary. Mar. Ecol. Prog. Ser. 14: 185-196

Dobbs, F. C., Guckert, J. B., Carman, K. R. (1989). Comparison of three techniques for administering radiolabeled substrates to sediments for trophic studies: incorporation by microbes. Microb. Ecol. 17: 237-250

Duyl, F. C. van, Kop, A. J. (1990). Seasonal patterns of bacterial production and biomass in intertidal sediments of the western Dutch Wadden Sea. Mar. Ecol. Prog. Ser. 59: $249-261$

Es, F. B. van, Meyer-Reil, L.-A. (1982). Biomass and metabolic activity of heterotrophic marine bacteria. Adv. microb. Ecol. 6: 111-170

Fallon, R. D., Newell, S. Y., Hopkinson, C. S. (1983). Bacterial production in marine sediments: will cell-specific measures agree with whole-system metabolism? Mar. Ecol. Prog. Ser. 11: 119-127

Fenchel, T., Blackburn, T. H. (1979). Bacterial and mineral cycling. Academic Press, New York

Fenchel, T., Straarup, B. J. (1971). Vertical distribution of photosynthetic pigments and the penetration of light in marine sediments. Oikos 22: 172-182

Findlay, S. E. G., Meyer, J. L., Edwards, R. T. (1984). Measuring bacterial production via rate of incorporation of $\left[{ }^{3} \mathrm{H}\right]$ thymidine into DNA. J. microbiol. Meth. 2: 57-72

Fuhrman, J. A., Azam, F. (1982). Thymidine incorporation as a measure of heterotrophic bacteriopiankton production in marine surface waters: evaluation and field results. Mar. Biol. 66: 109-120

Gomoiu, M. T (1967). Some quantitative data on light penetration in sediments. Helgoländer wiss. Meeresunters. 15: $120-127$

Hargrave, B. T. (1973). Coupling carbon flow through some pelagic and benthic communities. J. Fish. Res. Bd Can. 30: $1317-1326$
Hargrave, B. T., Prouse, N. J., Phillips, G. A., Neame, P. A. (1983). Primary production and respiration in pelagic and benthic communities at two intertidal sites in the upper Bay of Fundy. Can. J. Fish. Aquat. Sci. 40 (Suppl. 1): 229-243

Hedges, J. I., Stern, J. H. (1984). Carbon and nitrogen determinations of carbonate-containing solids. Limnol. Oceanogr. 29: $657-663$

Holmes, R. W., Mahall, B. E. (1982). Preliminary observations on the effects of flooding and desiccation upon the net photosynthetic rates of high intertidal estuarine sediments. Limnol. Oceanogr. 27: 954-958

Joint, I. R., Gee, J. M., Warwick, R. M. (1982). Determination of fine-scale vertical distribution of microbes and meiofauna in an intertidal sediment. Mar. Biol. 72: $157-164$

Lamontagne, I., Cardinal, A., Fortier, L. (1989). Environmental forcing versus endogenous control of photosynthesis in intertidal epilithic microalgae. Mar. Ecol. Prog. Ser. 51: $177-187$

Leach, J. H. (1970). Epibenthic algal production in an intertidal mudflat. Limnol. Oceanogr. 15: 514-521

Lee, S. Fuhrman, J. A. (1987). Relationships between biovolume and biomass of naturally derived marine bacterioplankton. Appl. environ. Microbiol. 53: 1298-1303

Li, W. K. W. (1983). Consideration of errors in estimating kinetic energy parameters based on Michaelis-Menten formalism in microbial ecology. Limnol. Oceanogr. 28: 185-190

Li, W. K. W., Dickie, P. M. (1987). Temperature characteristics of photosynthetic and heterotrophic activities: seasonal variations in temperate microbial plankton. Appl. environ. Microbiol. 53: 2282-2295

Lopez, G., Taghon, G., Levinton, J. (eds.) (1989). Ecology of marine deposit feeders. Springer-Verlag, New York

Mayer, L. M. (1989). Extracellular proteolytic enzyme activity in sediments of an intertidal mudflat. Limnol. Oceanogr. 34: 973-981

Meyer-Reil, L.-A. (1983). Benthic response to sedimentation events during autumn to spring at a shallow water station in the Western Kiel Bight. II. Analysis of benthic bacterial populations. Mar. Biol. 77: 247-256

Meyer-Reil, L.-A. (1984). Bacterial biomass and heterotrophic activity in sediments and overlying waters. In: Hobbie, J. E., Williams, P. J. LeB. (eds.) Heterotrophic activity in the sea. Plenum Press, New York, p. 523-546

Meyer-Reil, L.-A. (1987). Seasonal and spatial distribution of extracellular enzymatic activities and microbial incorporation of dissolved organic substrates in marine sediments. Appl. environ. Microbiol. 53: 1748-1755

Moriarty, D. J. W. (1986). Measurement of bacterial growth rates in aquatic systems from rates of nucleic acid synthesis. Adv. microb. Ecol. 9: 245-292

Moriarty, D. J. W., Pollard, P. C. (1981). DNA synthesis as a measure of bacterial productivity in seagrass sediments. Mar. Ecol. Prog. Ser. 5: 151-156

Moriarty, D. J. W., Pollard, P. C. (1982). Diel variation of bacterial productivity in seagrass (Zostera capricorni) beds measured by rate of thymidine incorporation into DNA. Mar. Biol. 72: 165-173

Moriarty, D. J. W., Pollard, P. C. (1990). Effects of radioactive labelling of macromolecules, disturbance of bacteria and adsorption of thymidine to sediment on the determination of bacterial growth rates in sediment with tritiated thymidine. J. microbiol. Meth. 11: 127-139

Moriarty, D. J. W., Pollard, P. C., Hunt, W. G., Moriarty, C. M. Wassenburg, T. J. (1985a). Productivity of bacteria and microalgae and the effect of grazing by holothurians in sediments on a coral reef flat. Mar. Biol. 85: 293-300 
Moriarty, D. J. W., White, D. C., Wassenberg, T. J. (1985b). A convenient method for measuring rates of phospholipid synthesis in seawater and sediments: its relevance to the determination of bacterial productivity and the disturbance artifacts introduced by measurements. J. microbiol. Meth. 3: 321-330

Phillips, N. W (1984). Role of different microbes and substrates as potential suppliers of specific, essential nutrients to marine detritivores. Bull. mar. Sci. 35: 283-298

Pomeroy, L. R., Deibel, D. (1986). Temperature regulation of bacterial activity during the spring bloom in Newfoundland coastal waters. Science 233: 359-361

Porter, K. G., Feig, Y. S. (1980). The use of DAPI for identifying and counting aquatic microflora. Limnol. Oceanogr. 25: 943-948

Riemann, B., Bell, R. T. (1990). Advances in estimating bacterial biomass and growth in aquatic systems. Arch. Hydrobiol. 118: 385-402

Ryther, J. H. (1965). The measurement of primary production. Limnol. Oceanogr. 1: 72-84

Schallenberg, M., Kalff, J., Rasmussen, J. B. (1989). Solutions to problems in enumerating sediment bacteria by direct counts. Appl. environ. Microbiol. 55: 1214-1219

This article was submitted to the editor
Shaffer, G. P., Onuf, C. P. (1985). Reducing the error in estimating annual production of benthic microflora: hourly to monthly rates, patchiness in space and time. Mar. Ecol. Prog. Ser. 26: 221-231

Strayer, D. (1988). On the limits to secondary production. Limnol. Oceanogr. 33: 1217-1220

Taylor, W. R. (1964). Light and photosynthesis in intertidal benthic diatoms. Helgoländer wiss. Meeresunters. 10: 29-37

Townsend, D. W., Cammen, L. M. (1988). Potential importance of the timing of spring plankton blooms to benthicpelagic coupling and recruitment of juvenile demersal fishes. Biol. Oceanogr. 5: 215-229

Varela, M., Penas, E. (1985). Primary production of benthic microalgae in an intertidal sand flat of the Ria de Arosa, NW Spain. Mar. Ecol. Prog. Ser. 25: 111-119

Watson, S. W., Novitsky, T. J., Quinby, H. L., Valois, F. W. (1977). Determination of bacterial number and biomass in the marine environment. Appl. environ. Microbiol. 33: 940-946

Whitney, D. E., Darley, W. M. (1979). A method for the determination of chlorophyll $a$ in samples containing degradation products. Limnol. Oceanogr. 24: 183-186

Manuscript first received: April 30, 1990

Revised version accepted: December 7, 1990 